\title{
EFFECT OF DIGGING DEPTH BELOW LASER SCRAPER BLADE ON FINE LEVELING DEGREE AND SOME SOIL PHYSICAL PROPERTIES \\ El-Sheikha, M. A. ${ }^{(1)}$; H. E. Osman ${ }^{(2)}$; M. A. Moustafa ${ }^{(1)}$ and M. F. Zayed ${ }^{(2)}$ \\ (1) Agric. Eng. Dept. Fac. of Agric. Mansoura Univ. \\ (2) Agric. Eng. Res. Inst., A.R.C., Dokki. Giza
}

\begin{abstract}
Field experiments were carried out during the agricultural season 2009 at Nasser El Noba, Kom Ombo, Aswan Governorate. The soil has been classified as a clay soil $(59.1 \%$ clay, $30.7 \%$ silt and $10.2 \%$ sand). The present work was to study the effect of chisel shankes depth blow laser scraper on fine land leveling degree and operative on some soil physical properties(bulk density, soil porosity, void ratio).

The study included four measuring depths under blade scraper $(10,15,18$, and $21 \mathrm{~cm})$, four tractor operating speeds $(3.45,4.19,4.86$ and $5.53 \mathrm{~km} / \mathrm{h})$ and tow slopes zero and $0.03 \%$ slope level were used for the experimental work. Increasing the quantity of fine pulverized soil was accompanied with a decrease in the large clod quantity for scraper. For leveling purposes, less fine pulverized soil quantity and more large clods are preferred. A little difference in the fine pulverized soil occurred with $0.03 \%$ leveling than that of the zero slope. Less fine pulverized soil and higher quantity of the large clod increased the mean weight diameter The higher values of the soil porosity mean better aeration, consequently, better seed bed that is proper for growing plants. Both of them were relatively affected by increasing measuring depth and operating speed, which was related to the soil bulk density. The resultant soil porosity at $0.03 \%$ slope was higher than that achieved at zero level. In summary increasing of measuring depth and operating speed decreased the value of soil porosity. Increasing of the measuring depth and operating speed decreased void ratio. The higher void ratio values were desired because of the larger chance for air presence in the seedbed.
\end{abstract}

\section{INTRODUCTION}

Leveling operation significantly increased the soil bulk density at soil layer depth of $10 \mathrm{~cm}$. This increment could be attributed to the effect of land leveling on breaking, loosening and compacting of soil particles. Also, it is evident that the change in soil bulk density was more at the surface layer (from $0-10 \mathrm{~cm}$ ). This change may be due to effectiveness of working depth of land levelers usage, which actually does not exceed the first layer $(0-10 \mathrm{~cm})$. While the load and compaction forces of the equipment usually influence deeper layers with damped effect causing an increase in soil bulk density (Michael -1990). The values of bulk density after laser and traditional leveling were higher in the bottom layers $(20-30 \mathrm{~cm})$ than the upper layers of $(10-$ $20 \mathrm{~cm})$ and $(0-10 \mathrm{~cm})$. The differences in bulk density values between laser and traditional leveling were $23.68 \%, 9.16 \%$ and $8.27 \%$ at the $(0-10 \mathrm{~cm})$, $(10-20 \mathrm{~cm})$ and $(20-30 \mathrm{~cm})$ layers depth, respectively. Also, he added that the increase of bulk density after leveling under laser in comparison with their values after traditional leveling is due to the increase in the compaction of laser than traditional land leveling (Youssef -1991). 
Abd El-Hafez et al. (1996) determined the bulk density $\left(\mathrm{g} / \mathrm{cm}^{3}\right)$ before and after carrying out the different land leveling treatments. Average values of the successive depths for soil profile $(0-60 \mathrm{~cm})$ were found to be 1.11 , $1.19,1.29$ and $1.36 \mathrm{~g} / \mathrm{cm}^{3}$ of initial, traditional, dead level and $0.02 \%$ slope treatments, respectively. During the growing season, and from year to year, natural and artificial causes after the soil conditions that influence the growth of plants in particular, machinery, traffic and the resulted compaction might change the structure of the soil considerably. The attendant changes in porosity, density, and strength of the soil in turn affect the content movement of air water, heat and nutrients in the soil . (Negi et al., -1980). The change in bulk density and the total porosity show a reverse behavior at different leveling treatments. It was clear that the mean relative decrease in total porosity was due to the compaction effect resulting from land leveling, which increased soil bulk density and consequently decreased soil porosity. The values of void at surface layer $(0-10 \mathrm{~cm})$ under different leveling uniformity coefficients indicate that void ratio was influenced by leveling operation, as it was decreased with different amounts depending upon the type of land leveling. This change is expected since void ratio is oppositely related to soil bulk density (Michael -1990).

Gabber (2001) found that the minimum value of soil porosity (43.3\%) was obtained by using precision land leveling with $0.03 \%$ land slope and forward speed (5.88 and $6.3 \mathrm{~km} / \mathrm{h}$ ), while the maximum value was $(46.8 \%)$ by using precision land leveling with zero slope and forward speed $(6.30 \mathrm{~km} / \mathrm{h})$. The value of soil porosity was decreased by increasing of the land slope and forward working speed. He added that the minimum value of void ratio was (0.763) using precision land leveling with $0.03 \%$ slope and forward working speed 5.88 or $6.3 \mathrm{~km} / \mathrm{h}$, while the maximum value was $(0.879)$ by using precision land leveling with zero slope and forward speed $(6.3 \mathrm{~km} / \mathrm{h})$. Increasing of the land slope and forward working speed decreased void ratio. Zayed (2005) found that Increasing the land slope and forward working speed decreased the value of soil porosity. Generally, it was noticeable that the void ratio was affected by the forward speed. It has same trend of the soil porosity, as both of them were functions of the soil pulverization and the soil bulk density. The higher void ratio values were desired because of the larger chance for air presence in the seedbed. El-Samra (2004) found that using traditional land leveling produced good results on soil physical and mechanical properties comparing with accuracy land leveling .While, using accuracy land leveling slope produced longest leveling duration. In addition, the suitable seedbed preparations system was chisel plough once forward by rotary tiller "Ch.-R." (Conservation tillage). It protected soil physical and mechanical properties comparing with rotary tiller "R." Moreover, it increased irrigation efficiency comparing with rotary tiller "R." (Minimum tillage) and twice chisel plough direction forward by wooden blade "2Ch.-L" (Traditional tillage).

Elbanna and witney (1987) found that, soil surface roughness values decreased with increasing number of tillage in the field. Also, for a clay soil at $25.01 \%$ moisture content: clods, equal or greater than $10 \mathrm{~cm}$ diameter were 
$43.11 \%, 39.84 \%, 37.2 \%$ and $15.70 \%$ by using moldboard ploughs, chisel ploughs, discs and rotary ploughs, respectively. Abo-Habaga (1987) showed that, secondary cultivation decreased the soil resistance of moldboard plough plots more that on chisel plough plots. In comparison to chisel plough plots, the moldboard plough plots yielded a higher proportion of large aggregates (layer than $10 \mathrm{~cm}$ ). The use of disc harrow reduced the size of large aggregates and the use of the rotary tiller had an even greater effect on the aggregates size; reducing the large aggregates substantially more. The rotary tiller improved the relief and reduced the surface roughness after both ploughing and chisel ploughing. El-Sheikha (1989) assembled chisel plough shanks in front of a rotary plough to obtain good penetration, good pulverization and proper seed bed preparation in one way ploughing with minimal power. The specially developed plough showed moderate pulverization, high specific fuel consumption and high field capacity. El-Nakib (1990) showed that the mean weight diameter increased by increasing of working depth and forward speed because few breaks down would be produced at higher speed and depth.

\section{MATERIALS AND METHODS}

The present work was to study the effect of digging depth blow laser scraper on fine land leveling degree and operative on some soil physical properties(bulk density, soil porosity, void ratio).

\section{Equipment:} follows

The LASER system equipment used in the present investigation are as

Transmitter: the Rugby 320 SG transmitter generates a long-range, rotating LASER beam that can be accurately and easily positioned to provide a control plane in $\mathrm{X}$ axis(single grade).

LASER Receiver: receiver is usually omni-directional and sensitive to the transmitted LASER beam. Other light being received is usually filtered out mechanically or electrically. Receiver is mounted on mast above scraper. The receiver has at least three different vertical sensing areas.

Control box: the control box accepts and processes signals from the machine mounted receiver. It displays these signals to indicate the drag bucket's position relative to the finished grade. When the control box is set to automatic, it provides electrical output for driving the hydraulic valve. The control box mounts on the tractor within easy reach of the operator.

Level eye: the alignment level eye was used with LASER transmitter to survey an area for elevation reading or for direct cut or fills reading.

The hydraulic solenoid valve: the solenoid control valve controls the flow of oil to the hydraulic ram, which raises and lowers the scraper. The hydraulic ram can be connected as a single or double acting ram. When connected as a single acting ram only one oil line is connected to the ram. An air breather is placed in the other connection of the ram to avoid dust contamination on the non-working side of the ram. In this configuration, the scraper can be lowered using its weight. 
Laser Scraper: the scraper bucket has a height of $53 \mathrm{~cm}$ and wide of $82 \mathrm{~cm}$ it is mounted types with hydraulic depth control and capacity of $1.3 \mathrm{~m}^{3}$. Utilizing implement a group of solid shanks ended with a set of blades in front of the scraper. This group of blade shanks is fixed on a steel rectangle crosssection bar $(10 \times 10 \mathrm{~cm})$, which in turn fitted on the both sides. The working depth of this blades group were 10,15, 18, and $21 \mathrm{~cm}$ deeper than the scraper blade to ensure soil disturbance before leveling.

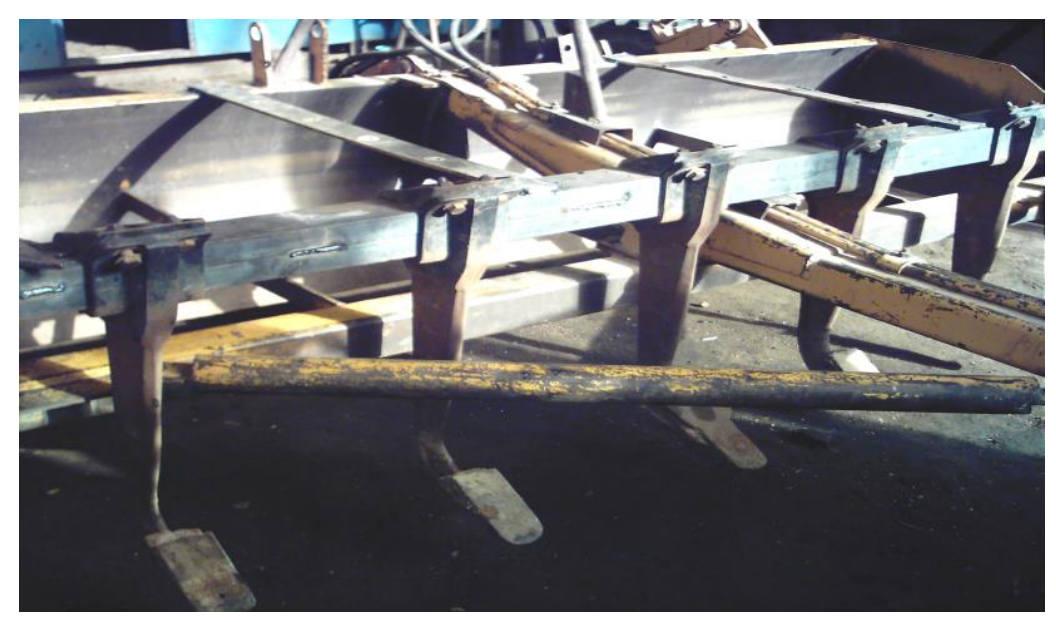

Fig. (A): Solid chisel shanks mounted of the scraper

The experimental area of 8-feddans, was divided into 4 plots,2-feddans each. The plots(1and2) zero level slope, while the plots(3and4) leveled at $0.03 \%$ slope .The tractor Massy Ferguson, $99.36 \mathrm{~kW}$ was used in clay soil.

\section{Experimental treatments}

Four measuring depths under blade scraper $(10,15,18$, and $21 \mathrm{~cm})$, four tractor operating speeds $(3.45,4.19,4.86$ and $5.53 \mathrm{~km} / \mathrm{h})$ and tow slopes zero and $0.03 \%$ slope level $(3 \mathrm{~cm}$ per $100 \mathrm{~m}$ lengthy) were the experimental parameters.

\section{The soil clod sample box:}

A rectangular open metal box $(50 \times 25 \times 15 \mathrm{~cm})$ was pushed into the tilled soil, with its length perpendicular to the travel direction in order to have a representative sample of the tilled soil. Three samples were taken from each experimental treatment and were air-dried for 48 hours and then weighed. The box had to be pressed smoothly in the tilled soil and when encountering a clod that was on the way of the box edge, it would be considered inside if more than $50 \%$ of it was inside, otherwise it was considered out. The box was pushed continuously and gently in the soil until it reached the bottom of the tilled layer.

\section{Sieves and core samplers:}

Three random samples were taken from the scraped soil to determine the mean weight diameter $(\mathrm{mm})$ using the five mesh sizes of 30 
$\mathrm{mm}, 20 \mathrm{~mm}, 10 \mathrm{~mm}, 5 \mathrm{~mm}$ and less than $2 \mathrm{~mm}$. Steel cylindrical cores also were used to take representative soil samples to estimate the soil moisture content and soil bulk density after leveling. All cores had the same volume of $100 \mathrm{~cm}^{3}$ with a sharp sloped outer side to avoid any resistance with the soil during taking samples and to prevent any soil compaction inside the cores.

\section{Measurements:}

\section{1- Soil moisture content, soil bulk density $\left(\rho_{b}\right)$}

Soil samples were taken using a core sampler with a special handle. It was smoothly pushed into the soil to the desired depth. After removing the core sampler, the excess soil was cut from both ends using a knife. Then the outer surface of the core, with the sample inside, was cleaned and weighed then put in the oven at $105^{\circ} \mathrm{C}$ for 24 hours. After cooling the core in the air, it was weighed and the difference between the wet and dry weight gave the water content $\left(W_{c}\right)$ of the sample. The dry weight of the soil $\left(W_{d}\right)$ equaled the weight of core filled with dried soil minus the weight of the empty core. Moisture content in percent $\left(\theta_{m}\right)$ was calculated using equation (1)

$$
\theta_{\mathrm{m}}=\frac{\mathrm{w}_{\mathrm{c}}}{\mathrm{w}_{\mathrm{d}}} \times 100
$$

where :

$\theta_{\mathrm{m}}=$ moisture content in percent

$\mathrm{W}_{\mathrm{c}}=$ wet mass, $\mathrm{g}$

$\mathrm{W}_{\mathrm{d}}=$ dry mass, $\mathrm{g}$

The soil bulk density was measured from 3 random samples obtained with the core sampler after land leveling. The soil samples were and the dry weights were calculated as explained before. Then, knowing the volume of the core sampler, the soil bulk density could be calculated using equation (2) . Soil Porosity (E) was calculated through equation(3) Void Ratio (e) Was calculated using the following formula(4).

$\rho_{\mathbf{b}}=\frac{\mathbf{W}_{\mathbf{d}}}{\mathbf{V}_{\mathbf{C}}}$

Where:

$\rho_{b}=$ Bulk density, $\mathrm{g} / \mathrm{cm}^{3}$,

$\mathrm{W}_{\mathrm{d}}=$ Dry weight of the soil sample inside the core

$V_{c}=$ Volume of the soil sample inside the core, $\mathrm{cm}^{3}$.

$\mathrm{E}=1-\frac{\rho_{\mathrm{b}}}{\rho_{\mathrm{s}}}$

Where:

$\mathrm{E}=$ porosity

$\rho_{\mathrm{b}}=$ Bulk density, $\mathrm{g} / \mathrm{cm}^{3}$,

$\rho_{s}=$ Density of the solid $\left(=2.65 \mathrm{~g} / \mathrm{cm}^{3}\right)$

$e=\frac{E}{1-E}$

Where:

$\mathrm{e}=$ void ratio 
$\mathrm{E}=$ porosity

FAO (1994) calculated the average clod size by using the following formula:

$$
\begin{aligned}
& M W D=1 / W(5 A+15 B+25 C+35 D+45 E+N F) \\
& W=A+B+C+D+E+F
\end{aligned}
$$

Where:

$\mathrm{MWD}=$ the mean soil clod diameter, $\mathrm{mm}$;

$\mathrm{W}=$ the mass of soil sample, $\mathrm{kg}$;

$A=$ the mass of soil passed from sieve $<10 \mathrm{~mm}, \mathrm{~kg}$;

$B=$ the mass of soil passed from sieve $<20 \mathrm{~mm}$ and left on sieve $10 \mathrm{~mm} \mathrm{~kg}$;

$C=$ the mass of soil passed from sieve $30 \mathrm{~mm}$ and left on sieve $20 \mathrm{~mm}, \mathrm{~kg}$;

$D=$ the mass of soil passed from sieve $40 \mathrm{~mm}$ and left on sieve $30 \mathrm{~mm}$, $\mathrm{kg}$;

$\mathrm{E}=$ the mass of soil passed from sieve $50 \mathrm{~mm}$ and left on sieve $40 \mathrm{~mm}, \mathrm{~kg}$;

$\mathrm{F}=$ the mass of soil retained on the largest aperture sieve $(50 \mathrm{~mm}), \mathrm{kg}$;

$\mathrm{N}=$ the mass of measured diameter of soil clods retained on the largest aperture sieve, $\mathrm{mm}$

\section{RESULTS AND DISCUSSION}

\section{The soil aggregate distribution:}

The soil aggregate distribution for the different soil particles after one pass of laser scraper was calculated and illustrated in figure (1). Soil mass sample with taken about $6 \mathrm{Kg}$, soil clod diameters bigger than $30 \mathrm{~mm}$ were very rare, so they did not have their own category. They were included in the category of 20-30 mm Nonetheless, mean weight diameters higher than $20 \mathrm{~mm}$, were associated with the modified scraper. Soil particles with mean weight diameters higher than $10 \mathrm{~mm}$ were about $72.3 \%$ for the plot (1) form mass sample compared to $72.6 \%$ for the plot(2) . Consequently, the laser scraper resulted in better soil pulverization. Therefore, it is evident that the modified scraper resulted in more desired soil structure at zero level. The effect of $0.03 \%$ slope on the soil aggregate distribution was indicated in Fig. (2). The pulverization of soil was affected by LASER scraper as a result of replication of the leveling cycles in the field. In plot (3) more fine pulverized soil because it needed more circulation in the field to achieve the required leveling. Soil particles with mean weight diameters of higher than $10 \mathrm{~mm}$ were about $83.44 \%$ for the plot (3) form mass sample compared to $86.27 \%$ for the plot(4). Increasing the quantity of fine pulverized soil was accompanied with a decrease in the large clod quantity for scraper. For leveling purposes, less fine pulverized soil quantity and more large clods are preferred. A little difference in the fine pulverized soil occurred with $0.03 \%$ leveling than that of the zero slope. Less fine pulverized soil and higher quantity of the large clod increased the mean weight diameter.

The mean weight diameter:

The mean weight diameter of the different soil particles under laser scraper was calculated. It was clear that the higher mean weight diameter value , $14.78,14.23-\mathrm{mm}$, at $0.03 \%$ slope compare to that small mean weight diameter, $12.7,13.07 \mathrm{~mm}$, at zero level. It was better soil pulverization 
because adding solid shanks on the frame of the laser scraper at equal distances a long the whole width of the scraper .

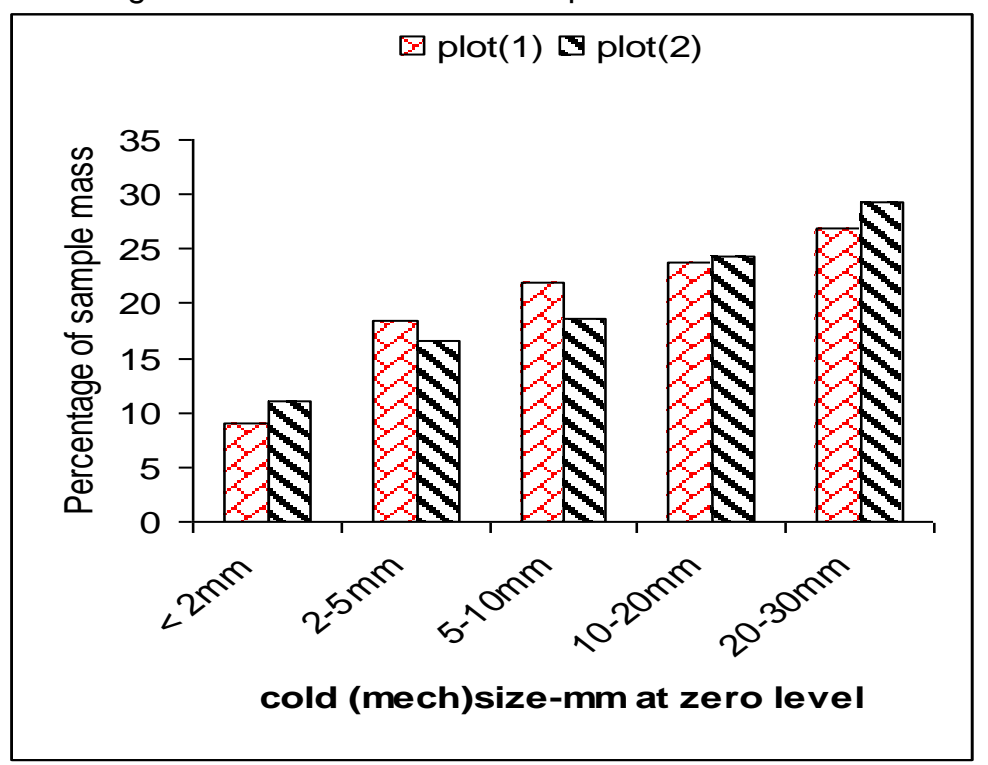

Fig. (1): The soil aggregate distribution at plot $(1,2)$.

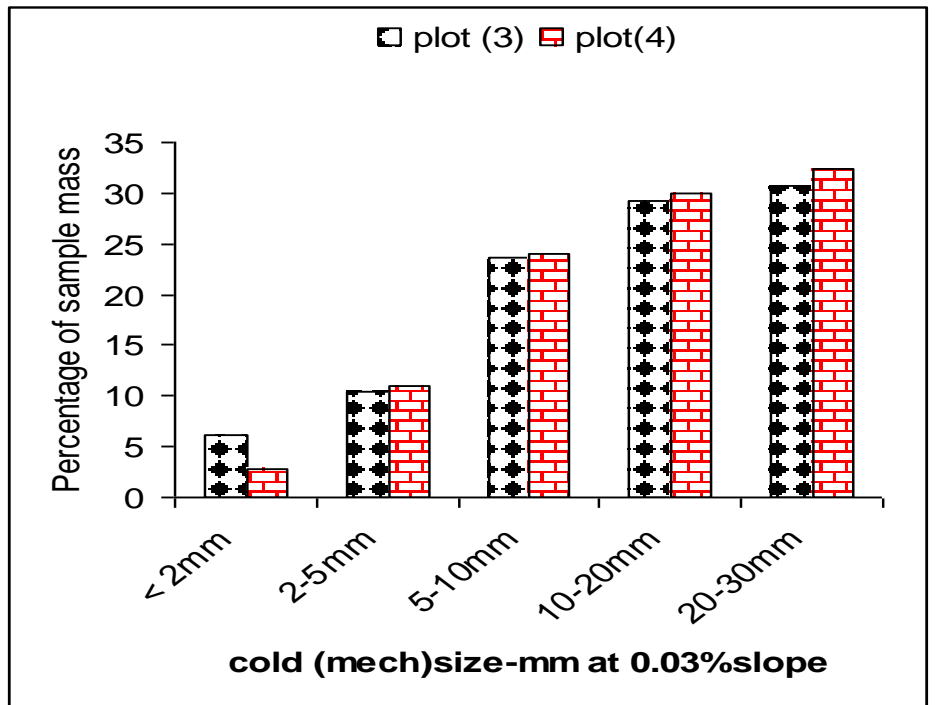

Fig. (2): The soil aggregate distribution at plot $(3,4)$.

\section{The soil bulk density $\left(\rho_{\mathrm{b}}\right)$ :}

The soil bulk density as affected by measuring depth and operating speed at moisture content from 13.33 to $15.94 \%$ was illustrated in figures (3AandB). The soil bulk density increased with increasing the measuring depth under blade scraper $(10,15,18 a n d 21 \mathrm{~cm})$ and operating speed 
$(3.45,4.19,4.86$ and $5.53 \mathrm{~km} / \mathrm{h})$ LASER leveling at $0 \%$ resulted in the value of soil bulk density of $1.102 \mathrm{~g} / \mathrm{cm}^{3}$ that was obtained by measuring depth $(10 \mathrm{~cm})$ at operating speed of $3.45 \mathrm{~km} / \mathrm{h}$, and $1.209 \mathrm{~g} / \mathrm{cm}^{3}$ that was obtained by measuring depth $(10 \mathrm{~cm})$ at operating speed of $5.53 \mathrm{~km} / \mathrm{h}$ while the value of soil bulk density of $1.319 \mathrm{~g} / \mathrm{cm}^{3}$ was achieved by using measuring depth $(21 \mathrm{~cm})$ at operating speed of $3.45 \mathrm{~km} / \mathrm{h}$ at and $1.331 \mathrm{~g} / \mathrm{cm}^{3}$ that was obtained by measuring depth $(21 \mathrm{~cm})$ at operating speed of $5.53 \mathrm{~km} / \mathrm{h}$, at zero level, Fig (3A).

At $0.03 \%$ slope, the minimum value of soil bulk density of $1.103 \mathrm{~g} / \mathrm{cm}^{3}$ that was obtained by measuring depth $(10 \mathrm{~cm})$ at operating speed of 3.45 $\mathrm{km} / \mathrm{h}$, and $1.116 \mathrm{~g} / \mathrm{cm}^{3}$ that was obtained by measuring depth $(10 \mathrm{~cm})$ at operating speed of $5.53 \mathrm{~km} / \mathrm{h}$ while the maximum value of soil bulk density of $1.263 \mathrm{~g} / \mathrm{cm}^{3}$ was achieved by using measuring depth $(21 \mathrm{~cm})$ at operating speed of $3.45 \mathrm{~km} / \mathrm{h}$ at and $1.329 \mathrm{~g} / \mathrm{cm}^{3}$ that was obtained by measuring depth $(21 \mathrm{~cm})$ at operating speed of $5.53 \mathrm{~km} / \mathrm{h}$ at $0.03 \%$ slope level Fig. (3B).
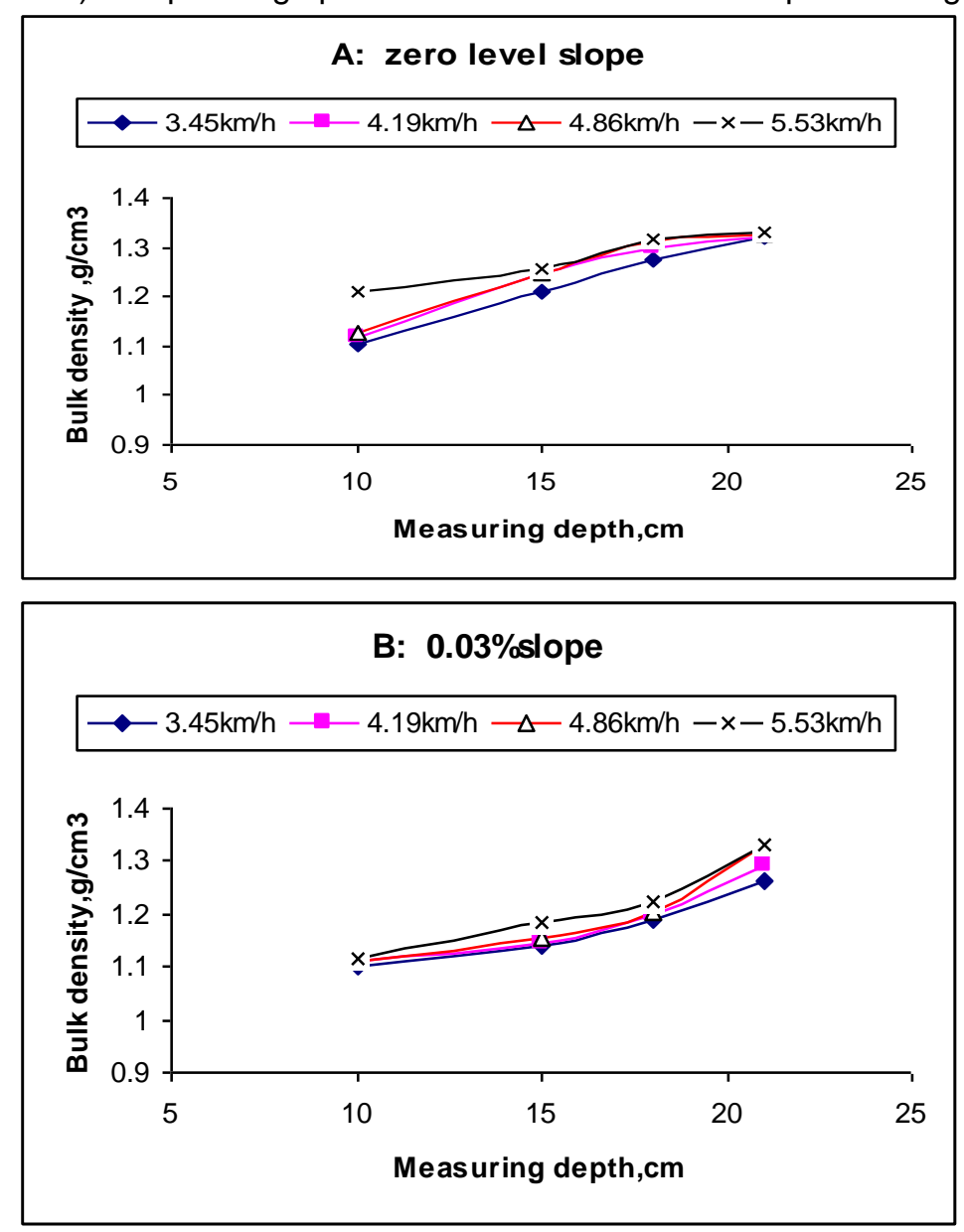

Fig. (3A-B): Effect of measuring depth and operating speed on soil bulk density 
In general, the leveling at $0 \%$ and $0.03 \%$ resulted in the same increasing trend with increasing the measuring depth and operating speed However, the leveling at $0 \%$ resulted in lower bulk density compared to the leveling at $0.03 \%$ which might be due to the lower cut and fill quantities required for the leveling at $0 \%$ slope and, consequently, lower pulverization.

On the other hand, the $0.03 \%$ level needed higher number of passes on each unit area; which resulted in a higher percentage of fine particles of soil and consequently, higher soil pulverization

\section{The Soil Porosity:}

The effect of measuring depth and operating speed on soil porosity at zero level was shown in Fig. ( 4A ). The results showed that bulk density and total soil porosity were inversely related. It was clear that increasing soil bulk density was accompanied by a decrease in soil porosity. The porosity values were influenced by leveling operation, as they decreased at different magnitudes depending upon the type of land leveling. The decrease in soil porosity with operating speed was expected since porosity is oppositely related to soil bulk density. The minimum value of soil porosity of $(54.5 \%$, $49.7 \%)$ was reached by measuring depth $(10 \mathrm{~cm}, 21 \mathrm{~cm})$ with operating speed of $5.53 \mathrm{~km} / \mathrm{h}$, respectively . While the maximum soil porosity value $(58.4 \%$, $50.2 \%)$ was reached by measuring depth $(10 \mathrm{~cm}, 21 \mathrm{~cm})$ with operating speed of $3.45 \mathrm{~km} / \mathrm{h}$, respectively at zero level.

The higher values of the soil porosity mean better aeration, consequently, better seed bed that is proper for growing plants. The effect of measuring depth and operating speed on soil porosity at $0.03 \%$ slope was shown in Fig. (4B). The results showed that bulk density and total soil porosity were inversely related. It was clear that increasing soil bulk density was accompanied by a decrease in soil porosity. The porosity values were influenced by leveling operation, as they decreased at different magnitudes depending upon the type of land leveling. The decrease in soil porosity with operating speed was expected since porosity is oppositely related to soil bulk density. The minimum value of soil porosity of $(57.8 \%, 49.8 \%)$ was reached by measuring depth $(10 \mathrm{~cm}, 21 \mathrm{~cm})$ with operating speed of $5.53 \mathrm{~km} / \mathrm{h}$, respectively .

While the maximum soil porosity value $(58.4 \%, 52.3 \%)$ was reached by measuring depth $(10 \mathrm{~cm}, 21 \mathrm{~cm})$ with operating speed of $3.45 \mathrm{~km} / \mathrm{h}$ ,respectively at zero level. The higher values of the soil porosity mean better aeration, consequently, better seed bed that is proper for growing plants. Both of them were relatively affected by increasing measuring depth and operating speed, which was related to the soil bulk density. The resultant soil porosity at $0.03 \%$ slope was higher than that achieved at zero level . In summary increasing of measuring depth and operating speed decreased the value of soil porosity.

\section{The Void ratio:}

The void ratio as affected by measuring depth and operating speed at zero level was illustrated in figure(5A). The minimum value of void ratio of $(1.19, .99)$ was reached by measuring depth $(10 \mathrm{~cm}, 21 \mathrm{~cm})$ with operating 
speed of $5.53 \mathrm{~km} / \mathrm{h}$, respectively . While the maximum void ratio value (1.4. 1) was reached by measuring depth $(10 \mathrm{~cm}, 21 \mathrm{~cm})$ with operating speed of $3.45 \mathrm{~km} / \mathrm{h}$,respectively at zero level. The void ratio as affected by measuring depth and operating speed at $0.03 \%$ slope was illustrated in figure $(5 \mathrm{~B})$. The minimum value of void ratio of $(1.37, .99)$ was reached by measuring depth $(10 \mathrm{~cm}, 21 \mathrm{~cm})$ with operating speed of $5.53 \mathrm{~km} / \mathrm{h}$, respectively .
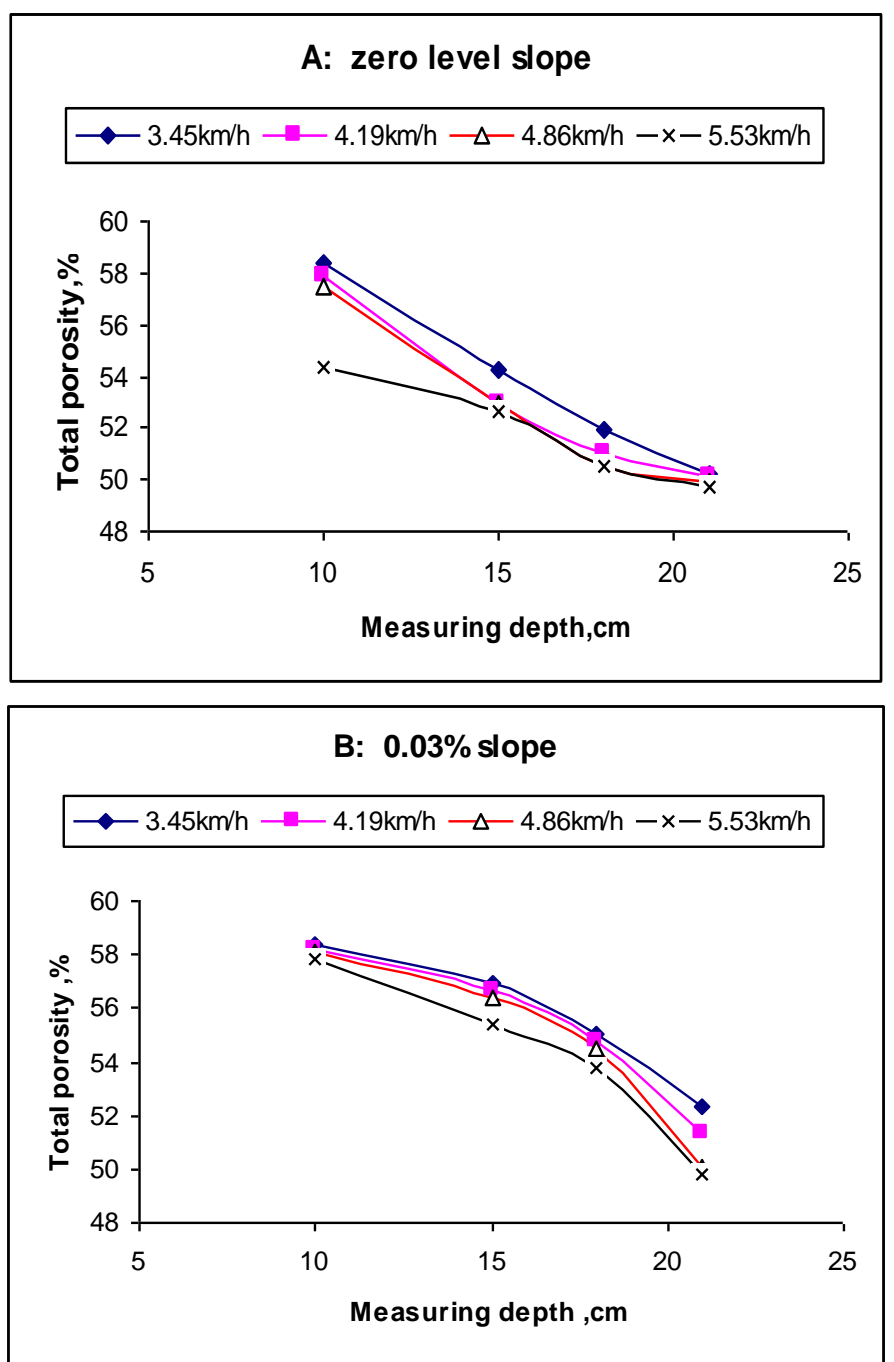

Fig. (4A-B): Effect of measuring depth speed on soil porosity.

While the maximum void ratio value $(1.4,1.09)$ was reached by measuring depth $(10 \mathrm{~cm}, 21 \mathrm{~cm})$ with operating speed of $3.45 \mathrm{~km} / \mathrm{h}$, respectively at $0.03 \%$ slope. Generally, it was noticeable that the void ratio was affected by measuring depth and operating speed. It has same trend of the soil porosity as both of them were functions of the soil pulverization and the soil 
bulk density. In general, void ratio was increased with adding (6)solid shanks on the main frame of the scraper at equal distances along the whole width of the scraper. It was also noticeable that the void ratio was higher with the slope leveling than that resulted with the zero leveling. Increasing of the measuring depth and operating speed decreased void ratio. The higher void ratio values were desired because of the larger chance for air presence in the seedbed.
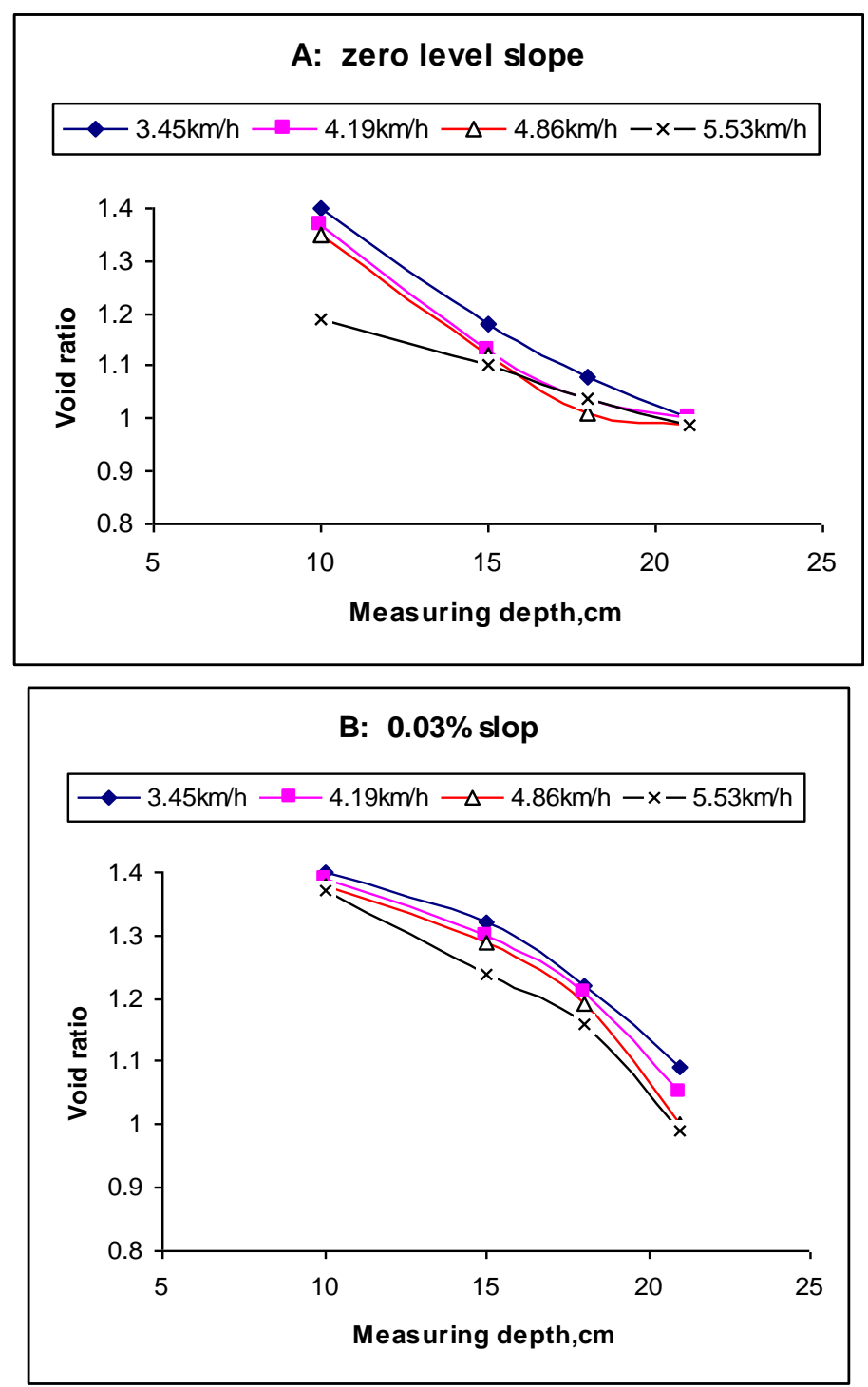

Fig (5A-B): Effect of measuring depth and operating speed on void ratio 


\section{CONCLUSIONS}

1- Increasing the quantity of fine pulverized soil was accompanied with a decrease in the large clod quantity for scraper. For leveling purposes, less fine pulverized soil quantity and more large clods are preferred. A little difference in the fine pulverized soil occurred with $0.03 \%$ leveling than that of the zero slope. Less fine pulverized soil and higher quantity of the large clod increased the mean weight diameter. The higher mean weight diameter value , $14.78,14.23-\mathrm{mm}$, at $0.03 \%$ slope compare to that small mean weight diameter, $12.7,13.07 \mathrm{~mm}$, at zero level. It was better soil pulverization because adding solid shanks on the frame of the laser scraper at equal distances a long the whole width of the scraper

2- The soil bulk density as affected by measuring depth and operating speed at moisture content from 13.33 to $15.94 \%$. In general, the leveling at $0 \%$ and $0.03 \%$ resulted in the same increasing trend with increasing the measuring depth and operating speed. The leveling at zero level resulted in lower bulk density compared to the leveling at $0.03 \%$ which might be due to the lower cut and fill quantities required for the leveling at $0 \%$ slope and, consequently, lower pulverization. On the other hand, the $0.03 \%$ level needed higher number of passes on each unit area; which resulted in a higher percentage of fine particles of soil and consequently, higher soil pulverization

3- The higher values of the soil porosity mean better aeration, consequently, better seed bed that is proper for growing plants. Both of them were relatively affected by increasing measuring depth and operating speed, which was related to the soil bulk density. The resultant soil porosity at $0.03 \%$ slope was higher than that achieved at zero level. In summary increasing of measuring depth and operating speed decreased the value of soil porosity. Increasing of the measuring depth and operating speed decreased void ratio. The higher void ratio values were desired because of the larger chance for air presence in the seedbed.

\section{REFERENCES}

Abd El-Hafez, S.A.; S.M. El-Hadidi; M.M. said and M.S.M. Abo Soliman. (1996). Improving surface irrigation efficiency through land leveling management. Misr J. Agric. Eng. , Cairo Univ. Irr. Conf., 3-4 April, 235 -244 .

Abo-Habaga, M. (1987). "Studies on the suitability of various soil tillage implements for small holding in Egypt" Ph.D. Thesis, Institute for land tech. derjustus libeling Univ. Giessen Germany.

E1-Nakib, A.E.A. (1990). Relation between fuel consumption and draft force with different tillage treatments in clay-loam soil. Misr J. Agric. Eng., 7(3): 224-237.

ElBanna, E. B. and B. D. Witney (1987). "Cone penetration resistance equation as a function of soil moisture and specific weight and clay ratio" J. Terramech. 24(4):41-56 
El-Samra, E., A. (2004). Effect of seed bed preparation system on the duration of land leveling by laser scraper ". M.Sc. thesis. Faculty of Agriculture Mansora University . Egypt .

El-Sheikha, M. A. (1989). Aquic and effective method to prepare seedbed for Egyptian farms. Misr J. Agric. Eng., 6 (3): 2 13-223.

FAO (1994). "Testing and evaluation of agricultural machinery and equipment". 110 Rome, Italy:33-34.

Gabber, K.A.E. (2001). Precision land leveling by using laser technology under the conditions of Fayoum Governorate. M.Sc. (thesis), Soils and Water Dept. Fac. of Agric. at El-Fayoum, Cairo Univ., Egypt.

Michael, K. M. (1990). Effect of leveling on the performance of some farm machinery. Ph.D. (thesis), Fac. of Agric., Moshtohor, Zagazig Univ., Egypt.

Negi, S. C.; E. McKyes; F. Taylor; E. Douglas and G. S. V. Raghavan. (1980). Crop performance as affected by traffic and tillage in a clay soil. Trans. of the ASAE, 30 (4) : $939-944$.

Youssef, S. F.(1991). A study of precision land leveling by LASER scraper in relation to water distribution and total yield. M.Sc. (thesis), Fac. of Agric., Zagazig Univ., Egypt.

Zayed, M.F. (2005). Modification of LASER technology in farm application. M. Sc. Thesis. Agric. Eng. Dept., Fac. of Agric., Mansoura University.

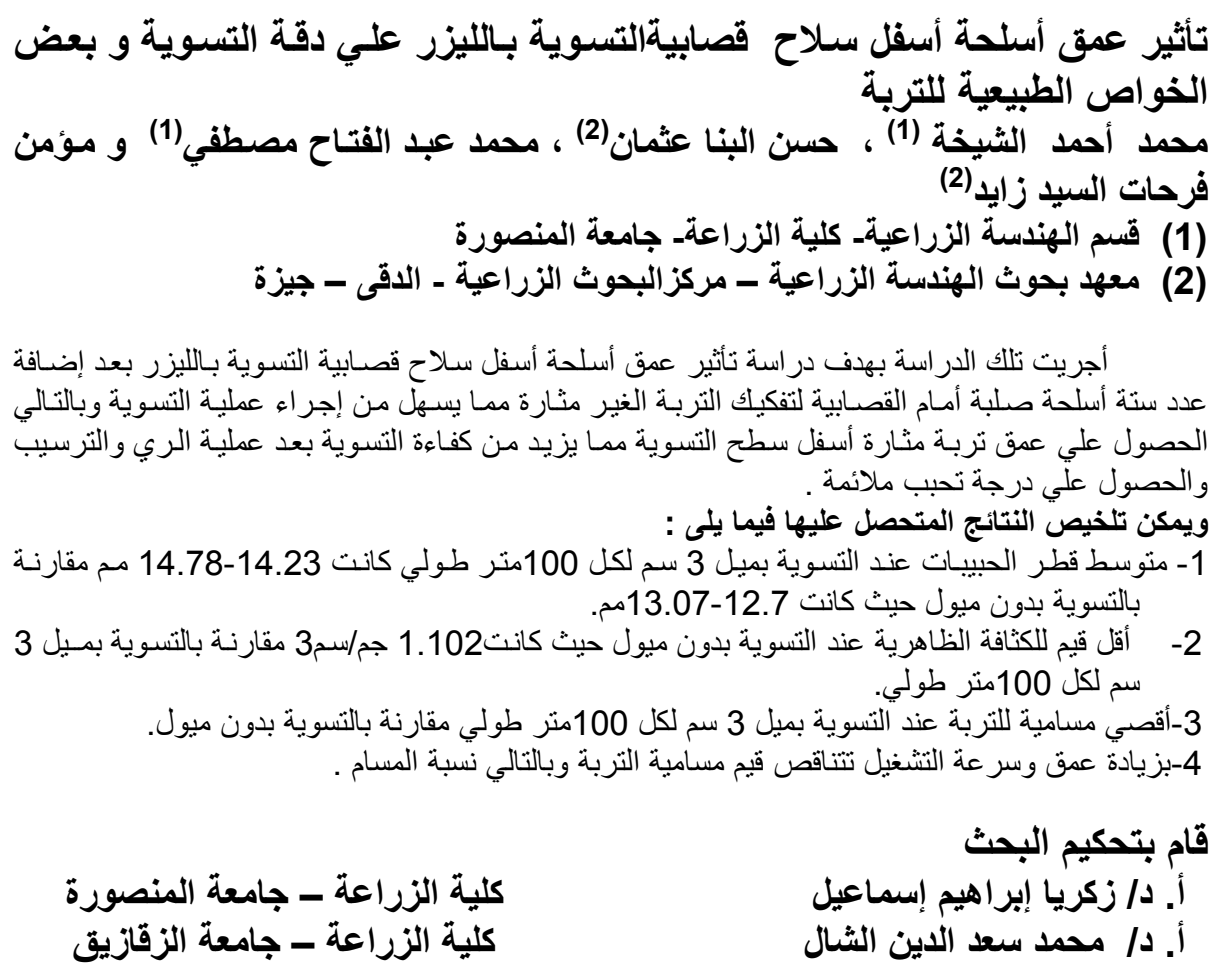

